\title{
EVALUATION OF LACTATE DEHYDROGENASE- A BIOCHEMICAL MARKER OF PREECLAMPSIA
}

\author{
Sushma V. Dev ${ }^{1}$, Hemalatha C. R2
}

${ }^{1}$ Assistant Professor, Department of Obstetrics and Gynaecology, Mysore Medical College and Research Institute (MMCRI), Mysore. ${ }^{2}$ Senior Resident, Department of Obstetrics and Gynaecology, Mysore Medical College and Research Institute (MMCRI), Mysore.

\section{ABSTRACT}

\section{BACKGROUND}

Serum LDH level is a useful predictive biochemical marker of cellular injury which reflects the severity of preeclampsia. It is a prognostic marker for both mother and foetus. Hence, its assay is useful to decide management of preeclampsia.

The aim of the present study was to evaluate the LDH levels in normal pregnancy and in preeclampsia.

\section{MATERIALS AND METHODS}

The prospective case-control study was conducted at the Department of Obstetrics and Gynaecology, Mysore Medical College and Research Institute, Mysore. A total of 150 pregnant women were studied and divided as groups of mild preeclampsia ( $\mathrm{n}=50$ ), severe preeclampsia $(n=50)$ and normotensive pregnant women $(n=50)$ as control group. LDH was assayed in patients and compared with control.

\section{RESULTS}

Significantly higher values of serum LDH were found in mild and severe preeclamptic women when compared to normal pregnant women $(\mathrm{p}<0.0001)$. Also, the values of serum LDH was significantly elevated in severe preeclamptic women when comparison was done between mild and severe preeclamptic women.

\section{CONCLUSION}

From the present study, it can be concluded that elevated high serum LDH levels significantly correlate with the severity of preeclampsia.

\section{KEYWORDS}

Preeclampsia, Serum LDH, Endothelial Dysfunction.

HOW TO CITE THIS ARTICLE: Dev SV, Hemalatha CR. Evaluation of lactate dehydrogenase- A biochemical marker of preeclampsia. J. Evolution Med. Dent. Sci. 2017;6(79):5572-5574, DOI: 10.14260/jemds/2017/1209

\section{BACKGROUND}

Pre-eclampsia is a multisystem disorder, unique to pregnant women after twenty weeks of gestation. It is a progressive disease with a variable mode of presentation and rate of progression. ${ }^{1}$ Preeclampsia is a clinical manifestation characterised by hypertension, proteinuria and oedema. Preeclampsia is one of the leading causes of maternal and foetal morbidity and mortality. 2,3,4 In India, incidence of preeclampsia as recorded from hospital statistics vary widely from $5-15 \% .^{5}$ The exact aetiology of preeclampsia is still remained unclear. ${ }^{6}$ Defective placentation and endothelial dysfunction are considered as the core features of preeclampsia.6,7 Endothelial cells dysfunction can contribute to inappropriate vasoconstriction, platelet aggregation, activation of the coagulation system and ultimately decreased blood flow to organs. $8,9,10$

Lactate dehydrogenase (LDH) is an intracellular enzyme and its elevated blood level indicates cellular death followed by its leakage to circulation.7,11,12 Serum LDH is abnormal in a host of disorders, therefore, the total serum LDH is a highly sensitive but nonspecific test.

'Financial or Other Competing Interest': None.

Submission 11-09-2017, Peer Review 23-09-2017,

Acceptance 25-09-2017, Published 30-09-2017.

Corresponding Author:

Dr. Sushma V. Dev,

\#5, 31 ${ }^{\text {ST }}$ Block,

JSS Layout, Mysore-570011

Karnataka.

E-mail: docsushmavdev@gmail.com

DOI: $10.14260 /$ jemds/2017/1209
In order to optimise the diagnostic value, LDH isoenzymes can be measured. This can be further used in making decision, regarding the management strategies to improve the maternal and foetal outcome.7,12,13,14,15 Recently, LDH level has been suggested as potential markers to predict the severity of preeclampsia and indicator for multiorgan involvement. ${ }^{11}$ The aim of the present study was to evaluate the LDH levels in normal pregnancy and in preeclampsia.

\section{MATERIALS AND METHODS}

The present prospective case-control study was conducted at the Department of Obstetrics and Gynaecology, Mysore Medical College and Research Institute, Mysore. This study was approved by Ethical Review Committee. In the study, 150 pregnant women were included. Here 100 pregnant women who presented with clinical symptoms and signs of preeclampsia were study group and they were categorised as group B. They were divided further into subgroups, Subgroup B1 which comprised 50 mild preeclampsia cases and Subgroup B2 with 50 severe preeclampsia cases. Also, 50 healthy normotensive pregnant women who were matched for maternal age, gestational age were selected as control group.

\section{Inclusion criteria}

Women with age 18-30 years with singleton pregnancy in the third trimester (28-40 weeks). In preeclampsia group, whose blood pressure was normal during the initial 20 weeks of gestation and with no prior history of hypertension were included. 


\section{Exclusion Criteria}

Prior history of pre-existing hypertension, diabetes, systemic or endocrine disorder, chronic renal disorder, epilepsy, liver disease, stroke, coronary artery disease, chronic infections, multiple pregnancy, women with labour pain were excluded from study.

Informed consent was taken from the participants. Detailed medical and family history was also taken. Blood samples were collected for serum LDH estimation by continuous spectrophotometric method. 16

Preeclampsia was diagnosed according to American College of Obstetrics and Gynecology (ACOG) criteria: a blood pressure higher than $140 / 90 \mathrm{mmHg}$ and proteinuria more than $300 \mathrm{mg} / 24$ hours were observed on at least two occasions more than 6 hours apart after the $20^{\text {th }}$ week of pregnancy. Preeclampsia cases were classified as severe if diastolic blood pressure increased to at least $110 \mathrm{mmHg}$, proteinuria $>5000 \mathrm{mg}$ per day and the presence of headache, visual disturbances, epigastric pain, oliguria, elevated LFT, elevated RFT, thrombocytopenia. ${ }^{2}$

The results were expressed as mean \pm SD and groups were compared using ANOVA. Statistical analysis was done by using SPSS software, version 22. The level of significance was set at $p$ value $<0.05$.

\section{RESULTS}

In the present study, total of 150 subjects were studied, of which 50 (33.3\%) were normotensives, remaining 100 patients $(66.6 \%)$ belonged to preeclampsia group with each 50 patients $(33.3 \%)$ in group B1 and group B2. The baseline characteristics of different study groups are presented in Table 1. Systolic and diastolic blood pressures (SBP, DBP) were significantly higher in preeclamptic groups when compared to normal pregnant women ( $p<0.0001)$, also SBP and DBP were significantly higher on comparison between group B1 and B2 ( $\mathrm{p}<0.001)$.

Mean LDH levels between the study groups are presented in Table 2. The mean LDH levels in the group A was $213.42 \pm$ 82.38 IU/L, mild preeclampsia group B1 was $516.1 \pm 175.91$ IU/L and severe preeclampsia group B2 was $697.24 \pm 218.11$ IU/L. The mean LDH levels are significantly higher in preeclampsia group compared to normal pregnant women ( $\mathrm{p}<0.0001)$. On comparing LDH levels between mild preeclampsia and severe preeclampsia, there was significant rise in the LDH levels with increasing severity of the disease $(\mathrm{p}<0.05)$. On analysis, it was found that high SBP and DBP were associated with higher levels of serum LDH $(\mathrm{P}<0.001)$. Table 3 presents comparison of LDH values between study groups. It is clear from the data that very high levels of LDH are frequently found in severe preeclampsia.

\begin{tabular}{|c|c|c|c|}
\hline Parameters & $\begin{array}{c}\text { Group A } \\
(\mathbf{n = 5 0 )}\end{array}$ & $\begin{array}{c}\text { Group B1 } \\
(\mathbf{n = 5 0 )}\end{array}$ & $\begin{array}{c}\text { Group B2 } \\
\mathbf{( n = 5 0 )}\end{array}$ \\
\hline $\begin{array}{c}\text { Age (years) } \\
\text { (mean } \pm \text { SD) }\end{array}$ & $23.46 \pm 2.78$ & $23.16 \pm 2.95$ & $22.75 \pm 2.14$ \\
\hline $\begin{array}{c}\text { Gestational age } \\
\text { (weeks) } \\
\text { (mean } \pm \text { SD) }\end{array}$ & $38.16 \pm 2.64$ & $37.82 \pm 1.88$ & $36.05 \pm 3.54$ \\
\hline $\begin{array}{c}\text { SBP (mmHg) } \\
\text { (mean } \pm \text { SD) }\end{array}$ & $116.4 \pm 4.32$ & $148 \pm 3.78^{* *}$ & $168 \pm 5.95^{* * \# \#}$ \\
\hline $\begin{array}{c}\text { DBP (mmHg) } \\
\text { (mean } \pm \text { SD) }\end{array}$ & $72 \pm 2.68$ & $95 \pm 4.94^{* *}$ & $114 \pm 3.85^{* * \# \#}$ \\
\hline Table
\end{tabular}

Table I. Baseline Characteristics in Different Groups ( $n=150)$

$\left({ }^{* *} \mathrm{p}<0.001\right.$, compared to group A and \#\#p $<0.001$, comparison between group B1 and group B2). SBP= Systolic blood pressure, $\mathrm{DBP}=$ Diastolic blood pressure. $\mathrm{n}=$ total number of subjects.

\begin{tabular}{|c|c|c|c|c|}
\hline Parameter & Group & Group & Group & $\begin{array}{c}\text { P } \\
\text { value }\end{array}$ \\
& A & B1 & B2 & LDH (IU/L) \\
$213.42 \pm$ & $516.1 \pm$ & $697.24 \pm$ & $<0.0001$ \\
(mean \pm SD) & 82.38 & 175.91 & 218.11 & \\
\hline \multicolumn{4}{|c|}{ Table 2. Mean LDH levels in Various Groups } \\
\hline
\end{tabular}

Table 2. Mean LDH levels in Various Groups

\begin{tabular}{|c|c|c|c|}
\hline Groups & $\begin{array}{c}\text { LDH } \\
<600 \text { IU } / \mathrm{L}\end{array}$ & $\begin{array}{c}\text { LDH } \\
600-800 \\
\text { IU } / \mathrm{L}\end{array}$ & $\begin{array}{c}\text { LDH }>800 \\
\text { IU } / \mathrm{L}\end{array}$ \\
\hline Group A $(n=50)$ & $50(46.3 \%)$ & - & - \\
\hline Group B1 $(n=50)$ & $35(32.4 \%)$ & $11(40.7 \%)$ & $4(26.7 \%)$ \\
\hline Group B2 $(n=50)$ & $23(21.3 \%)$ & $16(59.3 \%)$ & $11(73.3 \%)$ \\
\hline
\end{tabular}

\section{DISCUSSION}

Preeclampsia is considered an idiopathic multisystem disorder that is specific to human pregnancy. ${ }^{17}$ The prevention of preeclampsia complication has become main task to reduce maternal and perinatal morbidity and mortality. Treating obstetricians have to be more alert to diagnose early and manage comprehensively to prevent further progression of the disease. Several potential biochemical markers have been proposed to predict the severity of preeclampsia.8,10 According to Qublan et al, the multiorgan dysfunction in preeclampsia caused by vascular endothelial damage, including maternal liver, kidney, lungs, nervous system, coagulation system will lead to excessive LDH leakage and elevated levels in serum due to cellular dysfunction, which may cause the occurrence of preeclampsia. $^{7}$

LDH is an intracellular enzyme that converts lactic acid to pyruvic acid and elevated levels indicate cellular death.7,8 In our study, the levels of serum LDH was statistically significantly higher $(\mathrm{p}<0.0001)$ in preeclamptic women as compared to normal pregnant women as shown in Table 2 and Table 3. These results are similar to many other studies. $7,8,15,18,19$

It is evident from present study that progressively increased LDH level in severe preeclampsia indicates progression of cellular injury with severity of this disorder as supported by Sarkar et al. ${ }^{8}$ Progressively raising LDH correlates with worsening of preeclampsia, maternal and foetal complications as supported by many studies.7,8,11-15,18

\section{CONCLUSION}

From the present study, it can be concluded that elevated high serum LDH levels significantly correlate with the severity of preeclampsia. Hence, estimation of $\mathrm{LDH}$ in preeclampsia serves as a prognostic tool which is useful for early diagnosis and timely management to reduce maternal and foetal morbidity and mortality.

\section{ACKNOWLEDGMENT}

I would like to acknowledge the support given by our department faculty.

\section{REFERENCES}

[1] Dutta DC. Textbook of obstetrics. $7^{\text {th }}$ edn. New Central Book Agency Priv. Ltd 2014:219-40. 
[2] Cunningham FG, Leveno KJ, Bloom SL, et al. Williams obstetrics. 23 $3^{\text {rd }}$ edn. New York, NY: McGraw-Hill 2010:706-56.

[3] WHO, 2004. Bethesda, MD. Global burden of disease for the year 2001 by World bank region, for use in disease control priorities in developing countries, national institutes of health: WHO. Make every mother and child count. World Health Report, 2005, Geneva: World Health Organization, 2005.

[4] Shah MR. Hypertensive disorders in pregnancy. 1st edn. Published by Jaypee 2007:1-10.

[5] Mackey AP, Berg CJ, Atrash HK. Pregnancy related mortality from preeclampsia and eclampsia. Am J Obstet Gynecol 2001;97(4):533-8.

[6] Babu R, Venugopal B, Sabitha K, et al. Comparative study of liver and kidney biochemical parameters in normal and pre-eclamptic gestation. J curr trends clin med lab biochemistry 2013;1(3):26-30.

[7] Qublan HS, Ammarin V, Bataineh 0, et al. Lactic dehydrogenase as a biochemical marker of adverse pregnancy outcome in severe pre-eclampsia. Med Sci Monit 2005;11(8):CR393-7.

[8] Sarkar PD, Sogani S. Evaluation of serum lactate dehydrogenase and gamma glutamyl transferase in preeclamptic pregnancy and its comparison with normal pregnancy in third trimester. Int J Res Med Sci 2013;1(4):365-8.

[9] Kay HH, Zhu S, Tsoi S. Hypoxia and lactate production in trophoblast cells. Placenta 2007;28(8-9):854-60.

[10] Lopez-Jaramillo P, Casas JP, Serrano N. Preeclampsia: from epidemiology observation to molecular mechanisms. Brazil J Med Biol Res 2001;34(10):122735.

[11] Munde SM, Hazari NR, Thorat AP, et al. Gamma glutamyl transferase and lactate dehydrogenase as biochemical markers of severity of preeclampsia. Int J Med Health Pharm Biomed Eng 2014;8(1):50-3.
[12] Jaiswar SP, Amrit G, Rekha S, et al. Lactic dehydrogenase: a biochemical marker for preeclampsia-eclampsia. J Obstet Gynaecol India 2011;61(6):645-8.

[13] He S, Bremme K, Kallner A, et al. Increased concentrations of lactate dehydrogenase in pregnancy with preeclampsia; a predictor for birth of small for gestational age infants. Gynecol Obstet Invest 1995;39(4):234-8.

[14] Martin JN, May WL, Magann EF, et al. Early risk assessment of severe preeclampsia: admission battery of symptoms and laboratory tests to predict likelihood of subsequent significant maternal morbidity. Am J Obstet Gynecol 1999;180(6 Pt 1):1407-14.

[15] Umasatyasri Y, Vani I, Shamita P. Role of LDH (lactate dehydrogenase) in preeclampsia- eclampsia as a prognostic marker: an observational study. IAIM 2015;2(9):88-93.

[16] Schumann G, Bonora R, Ceriotti F, et al. IFCC primary reference procedures for the measurement of catalytic activity concentrations of enzymes at $37^{\circ} \mathrm{C}$. Part 2 . Reference procedure for the measurement of catalytic concentration of creatine kinase. Clin Chem Lab Med 2002;40(6):635-42.

[17] Norwitz ER, Hsu CD, Repke JT. Acute complications of preeclampsia. Clin Obstet Gynecol 2002;45(2):308-29.

[18] Andrews L, Patel N. Correlation of serum lactate dehydrogenase and pregnancy induced hypertension with its adverse outcomes. Int J Res Med Sci 2016;4(5):1347-50.

[19] Al-Jameil N, Tabassum H, Al-Mayouf H, et al. Liver function tests as probable markers of preeclampsia -a prospective study conducted in Riyadh. JCAM 2013: $1-4$. 